процесу фотосинтезу мікроводоростями. Визначено константу нестійкості ферментсубстратного комплексу ферменту з інгібітором. Встановлено розрахункове значення оптимальної концентрації $\mathrm{NO}_{3}^{-}$для приросту мікровдоростей типу Chlorella.

Література.

1. Манаков М. Н. Победимский Д.Г. Теоретические основы технологии микробиологических производств. - М.: Агропромиздат, 1990. $-272 \mathrm{c}$.

2. Полторак О. М., Чухрай О.С. Физико-химические основы ферментативного катализа / Ред. М.М. Поплавская. М.:Висшая школа., 1972. $-311 \mathrm{c.}$

3. Золотарьова О.К., Шнюкова Є.І., Сиваш О.О., Михайленко Н.Ф. Перспективи використання мікроводоростей у біотехнології / Під ред. О.К. Золотарьової. - К.: Альтерпрес, 2008. - 234 с.

4. Дячок В. В., Гуглич С.І., Левко О. Б. Вивчення впливу температури на кінетику поглинання вуглекислого газу мікроводоростями // Вісник Національного університету "Львівська політехніка". Хімія, технологія речовин та їх застосування.- 2015. - № 812. - C. $365-372$.

5. Dyachok V., Huhlych S., Yatchyshyn,Y., Zaporochets Y., Katysheva V. About the problem of biological processes complicated by mass transfer // Chemistry \& chemical technology.- 2017. - Vol. 11, №1. P. 111-116.

6. Stepan D. J., Shockey R. E., Moe T. A., Dorn R. 1. 2.3 carbon dioxide sequestration using microalgae systems // Energy and Environmental Research Center, University of North Dakota. - 2002 - N.1.- P.27

7. Глобальне потепління. Як Земля змінює своє обличчя. Спецпроект TCH.ua. https://tsn.ua/special-projects/warming//. - від 25 березня 2017.

8. Min-Kyu Ji, Reda A.I. Abou-Shanabab, Seong-Heon Kim, El-Sayed Salama, Sang-Hun Lee, Akhil N.Kabra, Youn-Suk Lee , Sungwoo Hong, Byong-Hun Jeon. Cultivation of microalgae species in tertiary municipal wastewater supplemented with $\mathrm{CO} 2$ for nutrient removal and biomass production // Ecological Engineering, 2013, 58, P. 142-148.

9. Guanyi Chen, Liu Zhao, Yun Qi. Enhancing the productivity of microalgae cultivated in wastewater toward biofuel production: A critical review // Applied Energy, 2015, V.137, P. 282-291.

10. Sheng-Yi Chiu Chien-Ya Kao Tsai-Yu Chen Yu-Bin Chang Chiu-Mei Kuo Chih-Sheng Lin. () Cultivation of microalgal Chlorella for biomass and lipid production using wastewater as nutrient resource // Bioresource Technology, 2015, 184, P. 179189.

\title{
References
}

1. Manakov M. N. Pobedymskyi D.H. (1990) Teoretycheskye osnovy tekhnolohyy mykrobyolohycheskykh proyzvodstv. M.: Ahropromyzdat,. 272.

2. PoltorakO.M.,ChukhraiO.S. (1972). Fyzyko-khymycheskye osnovy fermentatyvnoho katalyza / Red. M.M. Poplavskaia. M.:Vysshaia shkola.,.311.

3. Zolotar’ova O.K., Shnyukova Ye.I., Syvash O.O., Myxajlenko N.F. (2008). Perspektyvy vykorystannya mikrovodorostej u biotexnologiyi. K.: Al terpres. 234.

4. Dyachok V. V., Huhlych S. I., Levko O.B. (2015). Vyvchennia vplyvu temperatury na kinetyku poglynannya vuglekyslogo gazu mikrovodorostyamy, 812, 365-372.

5. Dyachok V., Huhlych S., Yatchyshyn Y., Zaporochets Y., Katysheva V. (2017) About the problem of biological processes complicated by mass transfer. 11,1,111-116.

6. Stepan, D. J. Shockey R. E., Moe T. A., Dorn R. 1. (2002) 2.3 carbon dioxide sequestration using microalgae systems, 1, 1-27.

7. Hlobalne poteplinnia. Yak Zemlia zminiuie svoie oblychchia. Spetsproekt TSN.ua. (2017) https://tsn.ua/special-projects/warming. vid 25 bereznia.

8. Min-Kyu Ji, Reda A.I. Abou-Shanabab, Seong-Heon Kim, El-Sayed Salama, Sang-Hun Lee, Akhil N.Kabra, Youn-Suk Lee , Sungwoo Hong, Byong-Hun Jeon. (2013) Cultivation of microalgae species in tertiary municipal wastewater supplemented with CO2 for nutrient removal and biomass production. Ecological Engineering, 58, 142-148.

9. Guanyi Chen, Liu Zhao, Yun Qi. (2015) Enhancing the productivity of microalgae cultivated in wastewater toward biofuel production: A critical review. Applied Energy, 137, 282-291.

10. Sheng-Yi Chiu Chien-Ya Kao Tsai-Yu Chen Yu-Bin Chang Chiu-Mei Kuo Chih-Sheng Lin. (2015) Cultivation of microalgal Chlorella for biomass and lipid production using wastewater as nutrient resource. Bioresource Technology, 184, 179-189.

Отримано в редакцію 05.05.2018

Прийнято до друку 25.06.2018
Received 05.05.2018

Approved 25.06.2018

\section{ВИЛУЧЕННЯ БІЛКІВ ЗІ СТІЧНИХ ВОД ХАРЧОВИХ ВИРОБНИЦТВ ШЛЯХОМ ЗАСТОСУВАННЯ НВЧ ВИПРОМІНЮВАННЯ}

\author{
Сабадаш В.В. канд. технд. наук, доцент \\ Гумницький Я.М. д-р техн. наук, професор \\ Національний університет «Львівська політехніка», м. Львів
}

\begin{abstract}
Анотація. В роботі приведено результати досліджень кінетики вилучення білків з модельного середовища, зміни оптичної густини дисперсій білка в результаті дії на досліджувану дисперсію випромінювання надвисокочастотного діапазону. Прочес денатурації дисперсій білка, щзо моделюють стічні води підприємств харчової промисловості, здійснювали під дією НВЧ випромінювання з частотою 2450 Ги. Обробленню піддавали водні дисперсії альбуміну та казеїну з масовою часткою сухих речовин 5\% за по-
\end{abstract}


тужності надвисокочастотного випромінювання 800 Вт. Контроль за процесом денатурації білка здійснювали за зміною оптичної густини досліджуваних дисперсій. Експериментальні дослідження показали, шуо ступінь вилучення альбуміну без застосування інших методів розділення становила 80\%, а казеїну 35\%. Виведено теоретичну залежсність для розрахунку зміни температури досліджуваного об'єкту від потужності генератора електромагнітних хвиль та часу дї на об'єкт випромінювання надвисокочастотного діапазону. В основу розрахунків кінетики нагрівання електролітів у полі дії електромагнітного випромінювання поставлено зв'язок між напруженістю електромагнітного поля, шуо генерується в резонаторній НВЧ-камері, та потужністю НВЧ-генератора. Експериментальне дослідження кінетики денатурації водних дисперсій білка показало хорошу збіжність експериментальних та розрахункових даних. За допомого приведеного рівняння можна з достатньою точністю визначати теплофізичні параметри прочесу нагрівання вологих об’єктів та дисперсій до $100{ }^{\circ} \mathrm{C}$, або для діелектриків з низьким вмістом вологи. Розроблений спосіб обробки стічних вод передбачає введення НВЧ модуля у технологічну схему очищення стічних вод біотехнологічних виробництв. Це дозволить здійснювати знезараження стічних вод та ефективного вилучення білкових сполук шляхом переведення білків у коагульований стан та збільшити ефективність очищення стічних вод.

Ключові слова: стічні води, білок, денатурація, НВЧ - випромінювання, теплообмін

\title{
REMOVAL OF PROTEINS FROM SEWAGE FROM FOOD INDUSTRIES BY APPLICATION OF MICROWAVE RADIATION
}

\author{
Sabadash V. V. PhD, Associate Prof., Gumnitsky J. M., Dr. of Tech.Sci., prof. \\ Lviv National Polytechnic University, Lviv, Ukraine
}

\begin{abstract}
The paper presents the results of investigations of the kinetics of protein extraction from the model dispersions and changes in the optical density of protein solutions as a result of influence of the ultrahighfrequency radiation on the test dispersion. The process of denaturation of protein solutions that simulate wastewater from food industry enterprises under the influence of microwave radiation at a frequency of $2450 \mathrm{~Hz}$ was carried out. The samples of aqueous dispersions of albumin and casein with a mass fraction of dry matter of $5 \%$ were treated of ultrahigh-frequency radiation of the power of $800 \mathrm{~W}$. Control of process of the protein denaturation was carried out by changing the optical density of the investigated samples. Experimental studies have shown that the degree of albumin excretion without application of other methods of separation was $80 \%$ and casein 35\%. The theoretical dependence for calculating the temperature change of the investigated object from the power of the generator of electromagnetic waves and the time of action on the object of radiation of the ultrahigh-frequency range was derived. The basis of calculations of the kinetics of heating of electrolytes in the field of electromagnetic radiation is the relationship between the intensity of the electromagnetic field generated in the chamber of microwave resonator and the power of the microwave generator. An experimental study of the kinetics of denaturation of aqueous dispersion of the protein showed good correlation of experimental and calculated data. Application of the given equation it is possible to determine with sufficient accuracy the thermophysical parameters of the process of heating the wet objects and solutions to $100^{\circ} \mathrm{C}$ or for dielectrics with low moisture content. The developed method of treatment of sewage involves the introduction of a microwave module in the technological scheme of sewage treatment of biotechnological industries. This will allow for the disinfection of sewage and the effective removal of protein compounds by converting proteins into a coagulated state and increasing the efficiency of wastewater treatment.
\end{abstract}

Key words: sewage, protein, denaturation, microwave radiation, heat exchange.

Постановка проблеми. Проблема очищення стічних вод від органічних забруднень дуже часто супроводжується труднощами, пов'язаними 3 низькою ефективністю вилучення колоїдів та високомолекулярних сполук. У випадку наявності білкових сполук у стічних водах виникає небезпека нецільової втрати не тільки цінних поживних речовин, але й небезпека створення живильного середовища для патогенної мікрофлори, що буде утруднювати процес очищення стічних вод. Відомо, що стічні води підприємств харчової промисловості забруднені органічними сполуками, та мінеральними речовинами [2]. Біотехнологічні виробництва займають одне 3 перших місць серед галузей промисловості, що скидають значну кількість стічних вод[1,2]. Це в основному дріжджові клітини, білки, вуглеводи, залишки масел, хлориди, фосфати, калій, азот, БПК загального стоку становить 1500-5000 мг/л.

Мета роботи - дослідити кінетику вилучення білків з модельного середовища під дією випромінювання надвисокочастотного діапазону та встановити закономірності зміни теплофізичних характеристик досліджуваних об'єктів в залежності від тривалості дії на них мікрохвильового випромінювання та потужності НВЧ-генератора.

Аналіз останніх досліджень і публікацій. У літературних джерелах міститься багато даних про способи вилучення білків з водних дисперсій, зокрема термічні [3], сорбційні методи із застосуванням 
природних та синтетичних сорбентів[2,3]. Встановлено, що сорбційна ємність цеоліту щодо альбуміну становить 14 мг/г.адс. Вказується, що наявність білка в стічних водах значно сповільнює процес адсорбційного вилучення фосфатів та амонію зі стічних вод і призводить до зменшення сорбційної ємності адсорбентів, оскільки молекули білка сорбуються на поверхні пор [1,2]. У попередніх публікаціях вказується, що процес адсорбції білків проходить у зовнішньо дифузійній області. Досягнення вищих показників якості очищення стічних вод потребує розробки новітніх технологій, зокрема застосування техніки НВЧ[3]. Використання НВЧ-випромінювання в різних галузях за останні десятиліття поширилося завдяки можливостям ефективного миттєвого нагріву, висушування, стерилізації, швидкого розігріву замороженої сировини і т.д.

Надвисокочастотні електромагнітні хвилі, проникаючи в об'єм матеріалу, що обробляється, діють швидко та рівномірно. Діелектрики та зневоднені об'єкти при цьому не підігріваються, а ті, що містять воду, можна за невеликий проміжок часу нагріти і висушити. Після обробки НВЧ випромінюванням структура матеріалу переважно не змінюється. Ефективність перетворення енергії електромагнітного поля на тепло зростає прямо пропорційно до частоти коливань і квадрату напруженості електромагнітного поля. Важлива перевага НВЧ нагріву - відсутність теплової інерційності, тобто можливість практично миттєвого включення і виключення теплового впливу на сировину, яка обробляється. Це дозволяє підтримувати високу точність регулювання процесу нагріву. ККД перетворення енергії НВЧ на тепло наближається до 100\%. [3,4]. Процес нагрівання модельних дисперсій в лабораторній установці відбувався у нестаціонарному режимі. Температура досліджуваного об'єкта змінювалася в часі. Для експериментальних досліджень використовували скляний контейнер, виготовлений з кварцового скла, що і $є$ неполярним діелектриком. У контейнері здійснювали нагрівання досліджуваної дисперсії шляхом пропускання електромагнітного випромінювання. Поверхня контейнера контактувала у конвективному і радіаційному теплообміні з навколишнім середовищем, що має більш низьку температуру. Принцип нагрівання під дією змінного електромагнітного поля на досліджуваний об'єкт спричинює поляризацію і пов'язані електричні заряди спрямовано здійснюють переміщення. Поляризація середовища збільшується зі збільшенням частоти та напруженості електромагнітного поля. У водних дисперсіях НВЧ випромінювання призводить до впорядкованого руху диполів води, що спричинює виділення тепла, яке рівномірно розподіляється в досліджуваному зразку [5]. Теплофізичні та оптичні характеристики досліджуваних матеріалів залежать від температури.

Експериментальні дослідження. Проведено серію дослідів, у яких досліджували процес денатурації дисперсій білка, що моделюють стічні води підприємств харчової промисловості. Дослідження кінетики вилучення білків 3 модельного середовища під дією випромінювання надвисокочастотного діапазону здійснювали шляхом оброблення водних дисперсій альбуміну та казеїну в полі дії НВЧ випромінювання з частотою 2450 Гц за потужності 800 Вт. Початкова концентрація альбуміну в дисперсії становила $\mathrm{C}_{\text {альб}}=$ 230 мг/дм ${ }^{3}$. Початкова концентрація казеїну (у вигляді натрію казеїнату) у дисперсії становила $\mathrm{C}_{\text {альб}}=230$ мг/дм³. Для стабілізації дисперсій білка рН доводили до 9 шляхом внесення 20\% NaOH. 1 дм ${ }^{3}$ водної дисперсії білка вносили у скляний контейнер висотою $15 \mathrm{~cm} \mathrm{і} \mathrm{діаметром} 10 \mathrm{~cm}$ та поміщали у експериментальну установку. Включали нагрів на 800Вт. Проби відбирали кожні 50с. Після проведення нагріву проби досліджуваних дисперсій охолоджували до температури $20^{\circ} \mathrm{C}$, відстоювали та аналізували на вміст білка фотометричним методом (біуретовим) [6] . Результати експерименту представлено на рис. 1.

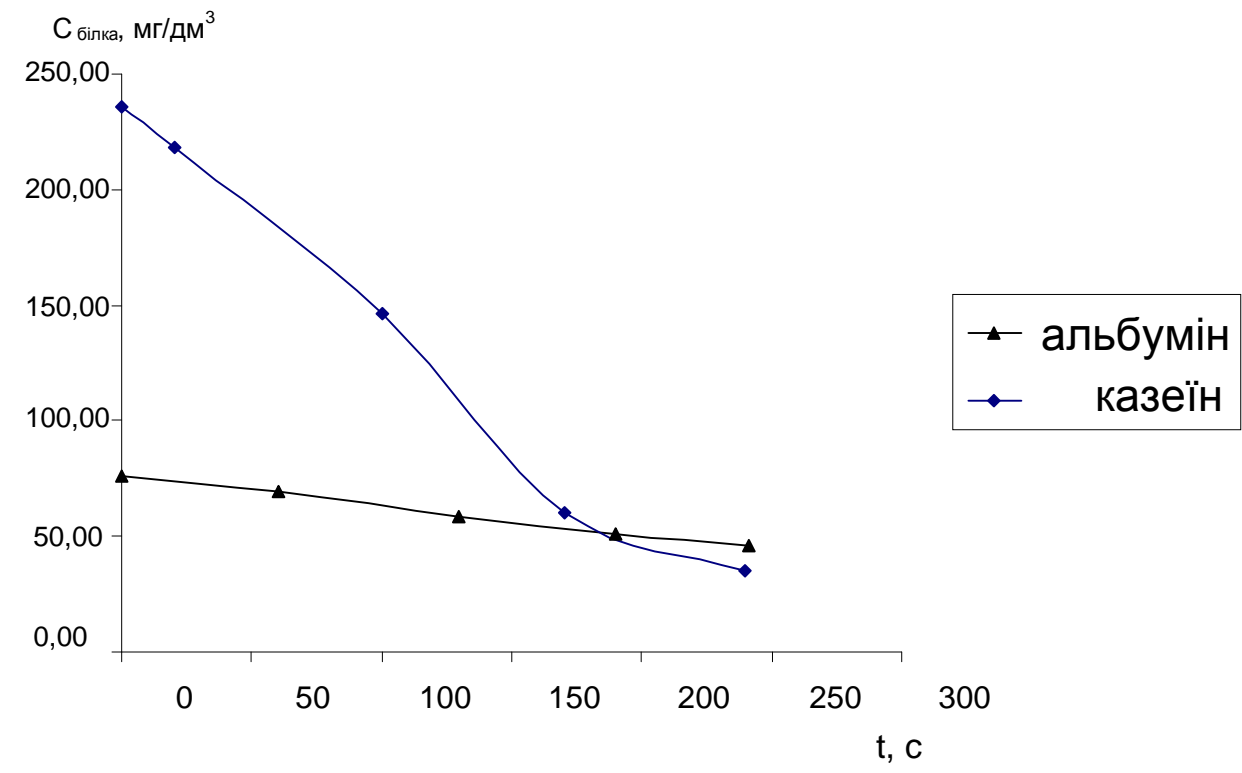

Рис.1. Кінетика вилучення білків 3 модельного середовища. 
Як видно з результатів дослідження під дією НВЧ поля відбувається зменшення концентрації білків у модельному середовищі за рахунок утворення осаду денатурованого білка. Експериментальні дослідження показали, що ступінь вилучення альбуміну без застосування інших методів розділення становила 80\%, а казеїну 35\%.В процесі денатурації спостерігається зміна оптичної густини дослідних зразків. Результати дослідження приведені на рис. 2.

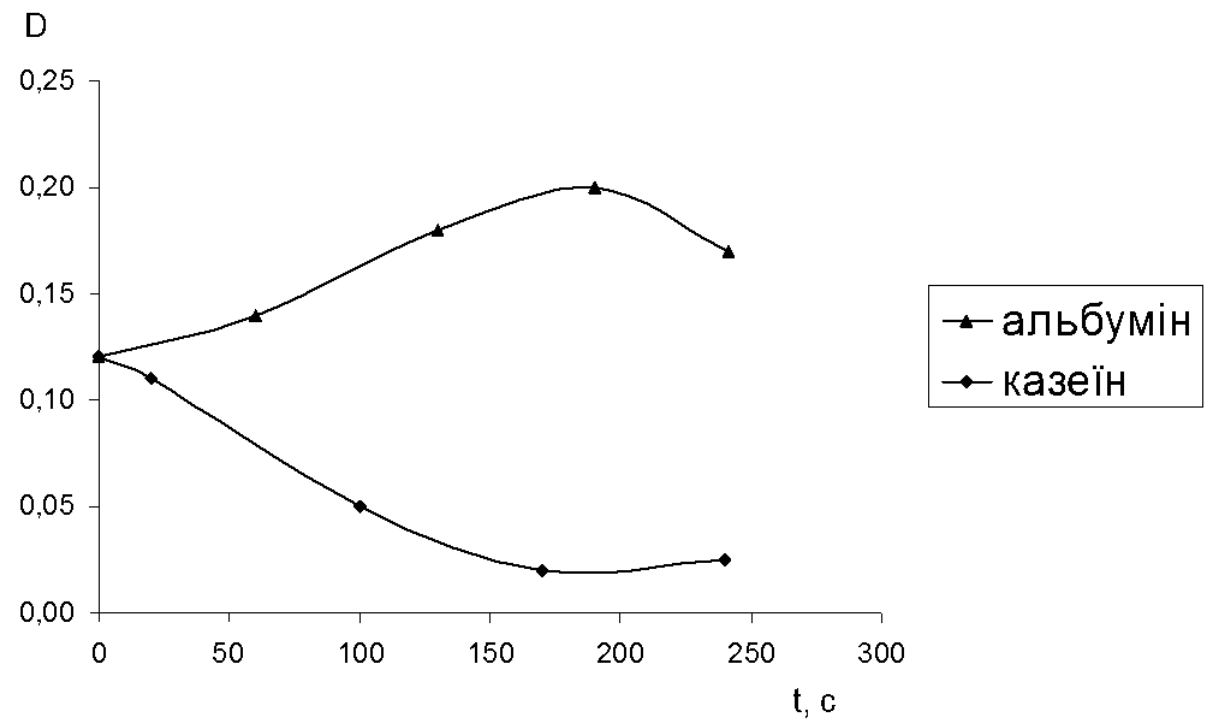

Рис. 2. Зміна оптичної густини водних дисперсій білка.

Зв'язок між напруженістю електромагнітного поля, що генерується в резонаторній НВЧ-камері, та потужністю генератора електромагнітних хвиль надвисокочастотного діапазону описується загально відомими рівняннями електродинаміки [7,8].

В результаті впливу НВЧ променів конфігурація білків, руйнується. Денатурований у такий спосіб білок втрачає свою біологічну активність. На процес денатурації має вплив температура середовища, яка буде збільшуватися в залежності від потужності електромагнітного випромінювання, що діє на досліджуваний об'єкт[9].

Розрахункову формулу для визначення середнього значення питомої потужності внутрішніх джерел теплоти під час нагріву у надвисокочастотному полі представлено у [8]:

$$
\omega=\frac{P}{l S} \frac{1}{R} \int_{0}^{R} e^{-\frac{r}{l}} d r
$$

де $\omega$ - потужність внутрішніх джерел теплоти, Вт/м³

$S$ - площа поверхні об'єкта, що піддається нагріву, м²;

$V$ - об'єкта об'єм продукту, м ${ }^{3}$;

$R=V / S$ - відношення об'єму до площі поверхні досліджуваного об'єкта, м;

$l$ - глибина проникнення НВЧ - випромінювання у досліджуваний об'єкт, м;

Проінтегрувавши (1) одержимо:

$$
\omega=\frac{P}{V} \frac{l}{R}\left(1-e^{-\frac{R}{l}}\right)
$$

де $\mathrm{P}$ - потужність нагрівання тіла довільної форми в момент часу $\tau$, Вт:

$$
P=c m \frac{\left(T_{2}-T_{1}\right)}{\tau},
$$

де m - маса об'єкта, що піддається нагріву, кг;

$\mathrm{T}_{1}$ i $\mathrm{T}_{2}$ - початкова та кінцева температури досліджуваного об’єкта ${ }^{\circ} \mathrm{K}$;

$\mathrm{c}$ - теплоємність, Дж/(кг·К);

$\tau-$ час, c.

Рівняння (2) матиме наступний вигляд: 


$$
\omega=\frac{c m\left(T_{2}-T_{1}\right)}{\tau V} \frac{l}{R}\left(1-e^{-\frac{R}{l}}\right)
$$

Температура нагрівання тіла довільної форми в момент часу $\tau$ після впливу НВЧ поля буде рівна:

$$
\begin{gathered}
T_{2}=\frac{\omega V \tau R}{c m l\left(1-e^{-\frac{R}{l}}\right)}+T_{1}, \text { або } \\
T_{2}=\frac{P_{2} \tau R}{c m l\left(1-e^{-\frac{R}{l}}\right)}+T_{1},
\end{gathered}
$$

де $\mathrm{P}_{2}=\omega \cdot \mathrm{V}$ - потужність НВЧ-генератора, Вт;

Для перевірки теоретичних даних ми дослідили зміну температури досліджуваного об’єкта(рис. 3).

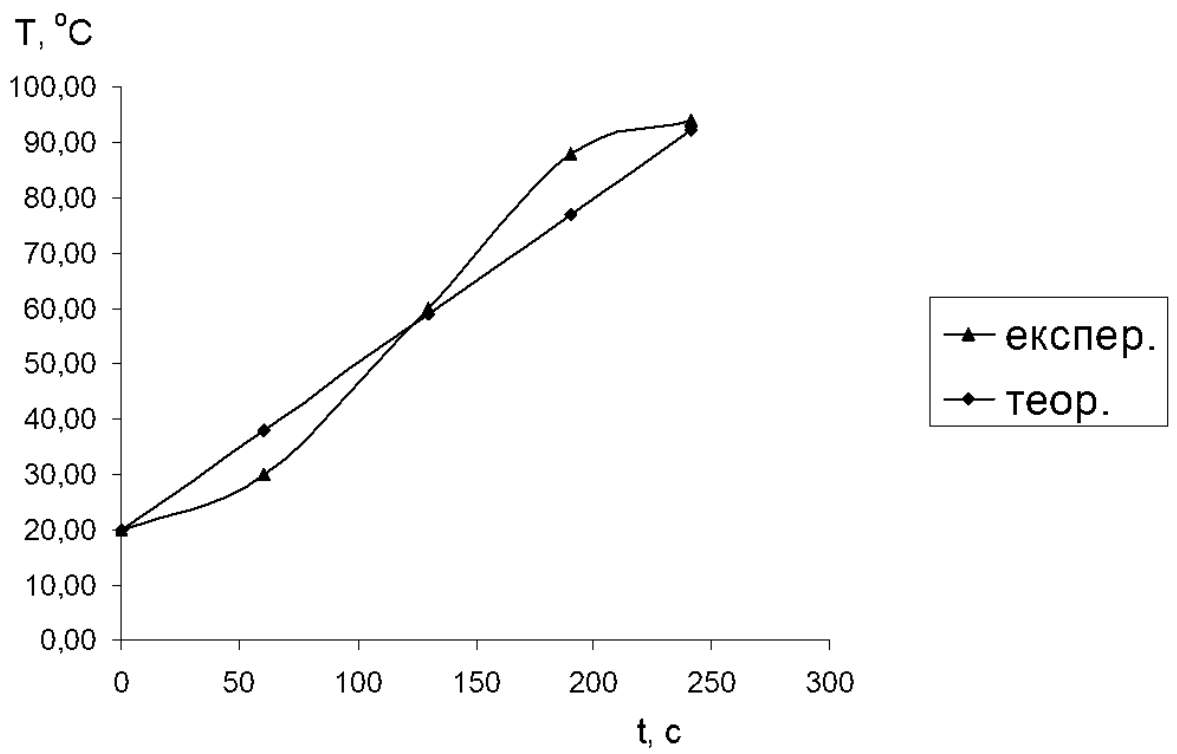

Рис. 3. Зміна температури водних дисперсій білка під впливом НВЧ випромінювання.

Порівняння теоретичних та експериментальних даних свідчить про те, що за допомогою рівняння (5) можна визначати теплофізичні параметри процесу до $100^{\circ} \mathrm{C}$ (або для діелектриків з низьким вмістом вологи)з достатньою точністю.

Висновки. Отже, аналіз результатів експериментальних досліджень використання випромінювання надвисокочастотного діапазону показав, що генератори електромагнітних хвиль надвисокочастотного діапазону можна використовувати для вилучення білків з водних дисперсій, зокрема з промислових стоків з високим вмістом білка. Дана технологія дає змогу забезпечити скорочення тривалості процесу обробки та мікробіологічну стабільність продукції. Перспективи більш широкого застосування НВЧвипромінювання пов'язані з розробкою і впровадженням НВЧ-установок нового покоління.

\section{Література}

1. Мацуська О. В. Очищення стоків від білків природними сорбентами/ О. В. Мацуська, Р. П. Параняк, Я. М. Гумницький //Науковий вісник Львівського національного університету ветеринарної медицини та біотехнологій ім. Гжицького. - 2011. - Т. 13, № 2(2). - С. 255-261

2. Гумницький Я.М. Кінетика адсорбції альбуміну природним сорбентом/ Я.М. Гумницький, (А.М. Гивлюд), В.В.Сабадаш //Наукові праці ОНАХТ. - Одеса, 2015. - Вип. 47.- Т.1. - С. 133-139.

3. Beszedes S. Application of thermal and microwave pre-treatments for dairy wastewater sludge / S. Beszedes, G. Szabo, G. Geczi. // International Journal Of Engineering. - 2012. - №10. - C. 231-235.

4. Сабадаш В.В. Очищення стічних вод у полі дії надвисокочастотного випромінювання // Вчені записки ТНУ імені В.І. Вернадського. Серія: Технічні науки. - 2018. - том 29 (68), № 1. - С. 184-188.

5. Effects of heat processing methods on protein subfractions and protein degradation kinetics in dairy cattle in relation to protein molecular structure of barley grain using advanced molecular spectroscopy / [L. L. Prates, Y. Lei, B. Refat тa iн.]. // Journal of Cereal Science. - 2018. - №80. - C. 212-220. 
6. Trimm H. H. Analytical Chemistry: Methods and Applications / CRC Press. - 2011. - 380P.

7. Потапов В. О. До питання розрахунку внутрішніх джерел теплоти під час мікрохвильової обробки харчових продуктів/ В. О. Потапов, В. В. Качалов, С. В. Михайлова // Прогресивні техніка та технології харчових виробництв ресторанного господарства і торгівлі. - 2013. - Вип. 1(2). - С. 73-81.

8. Kostas E. T. The application of microwave heating in bioenergy: A review on the microwave pre-treatment and upgrading technologies for biomass. /E. T. Kostas, D. Beneroso, J. P. Robinson //Renewable and Sustainable Energy Reviews. - 2017. - 77. - P. 12-27.

9. Meda V. Microwave heating and the dielectric properties of foods / V. Meda, V. Orsat, V. Raghavan // The Microwave Processing of Foods (Second Edition) / V. Meda, V. Orsat, V. Raghavan. - Sawston: Woodhead Publishing, 2017. - P. 23-43.

References

1. Matsuska, O. V., Paranyak, R. P., Gumnytskyy, YA. M. (2011). "Purification of effluents from natural proteins by natural sorbents”, Naukovyy visnyk Lvivskoho natsionalnoho universytetu veterynarnoyi medytsyny ta biotekhnolohiy im. Gzhytskoho, vol. 13, № 2 (2), pp. 255-261.

2. Gumnytskyy, YA. M., Hyvlyud, A. M., Sabadash, V. V. (2015). "Kinetics of albumin adsorption by natural sorbent", Naukovi pratsi Odes'koyi natsional'noyi akademiyi kharchovykh tekhnolohiy, vol. 47 (1), pp. 133-137.

3. Beszédes, S., Szabó, G., Géczi, G. (2012). Application of thermal and microwave pre-treatments for dairy wastewater sludge, Annals of the Faculty of Engineering Hunedoara, vol. 10(3), pp. 231-235.

4. Sabadash V.V. (2018). "Purification of sewage in the field of ultrahigh-frequency radiation", Ucheni zapiski TNU named after V.I. Vernadsky Series: Engineering, vol. 29 (68), No 1, pp. 184-188.

5. Prates, L. L., Lei, Y., Refat, B., Zhang, W., Yu, P. (2018). Effects of heat processing methods on protein subfractions and protein degradation kinetics in dairy cattle in relation to protein molecular structure of barley grain using advanced molecular spectroscopy. Journal of Cereal Science, 80, 212-220.

6. Trimm, H. H. (Ed.). (2011). Analytical Chemistry: Methods and Applications. CRC Press.

7. Potapov, V. O., Kachalov, V. V., Mykhaylova, S. V. (2013). "To the question of calculation of internal sources of heat during microwave processing of food products", Prohresyvni tekhnika ta tekhnolohiyi kharchovykh vyrobnytstv restorannoho hospodarstva i torhivli, vol. 1 (2), pp. 73-81.

8. Kostas, E. T., Beneroso, D., Robinson, J. P. (2017). The application of microwave heating in bioenergy: A review on the microwave pre-treatment and upgrading technologies for biomass. Renewable and Sustainable Energy Reviews, 77, 12-27.

9. Meda, V., Orsat, V., Raghavan, V. (2017). Microwave heating and the dielectric properties of foods. In The Microwave Processing of Foods (Second Edition), pp. 23-43.

Отримано в редакцію 17.05 .2018

Прийнято до друку 30.06.2018

Received 17.05.2018

Approved 30.06.2018

УДК 662.997

DOI: http://dx.doi.org/10.15673/swonaft.v82i1.1012

\title{
ИНТЕГРАЦИЯ ПРОЦЕССА ТЕПЛООБМЕНА СОЛНЕЧНОЙ УСТАНОВКИ
}

\author{
Селихов Ю.А., канд. техн. наук., профессор, Коцаренко В.А., канд. техн. наук., профессор, \\ Национальный технический университет \\ «Харьковский политехнический институт», г. Харьков
}

\begin{abstract}
Аннотация. Европейские страны демонстрируют высокие возможности простого преобразования солнечной энергии в тепловую энергию, которая может успешно использоваться для обеспечения различного рода технологических, отопительных и бытовых потребностей. Кроме того, ввод в эксплуатаичю солнечных установок улучшает экологическую ситуацию района потребления тепловой энергии за счет снижения объемов выбросов загрязняющих веществ, к которым относятся продукты сгорания органического топлива, используемого для производства тепловой энергии. В настоящее время в южных районах Украины уже используются солнечные установки для горячего водоснабжения и отопления. Однако, внедрение новых энергетических и экономически выгодных установок идет медленными темпами, что объясняется довольно высокими стоимостными показателями, как отечественных, так и зарубежных установок. Таким образом, на наш взгляд, является актуальной концепция создания новых солнечных установок, наиболее привлекательных для потенциального потребителя. Реализация данной концепции возможна при таком варианте исполнения солнечных установок, когда затраты на выработку тепловой энергии с помощью этих установок будут ниже уровня суммарных затрат на получение тепловой энергии традиционными способами (в частности, в котельных установках). Одновременно с этим, срок окупаемости солнечных установок должен быть соизмерим с гарантийным сроком их эксплуатации. Для выполнения поставленных условий представляется иелесообразным разработка таких конструкций солнечных коллекторов, которые позволяли бы минимизировать затраты на их изготовление, монтаж и обслуживание. Это может достигаться за счет использования дешёвых отечественных материалов, выпуск которых гарантирован в достаточных объемах на протяжении длительного срока. Разработка, изготовление и внедрение двухконтурных солнечных установок позволило круглогодично эксплуатировать солнечный коллектор, но капитальные и эксплуатационные затраты при этом были на таком уровне, что для полной окупаемости солнечной установки могло понадобиться более
\end{abstract}

